7 Proceedings of the Second Annual Forestry Symposium 1996: Management and Sustainable Utilization of Forest Resources, Sri Lanka, 6-7 December 1996. (Eds. Amarasekera, HS, Ranasinghe, D M S HK and Finlayson, $W$. Published by Department of Forestry and Environmental Science, University of Sri Jayewardenepura, Sri Lanka (1998)

\title{
INTEGRATING FOREST RESOURCE VALUES INTO NATIONAL INCOME ACCOUNTING: AN EMPIRICAL ANALYSIS
}

\author{
Saliya De Silva and H.B. Kotagama \\ Department of Agricultural Economics, University of Peradeniya
}

\begin{abstract}
The traditional System of National Accounts (SNA) neglects the Total Economic Value (TEV) of the forest resource, and any degradation to which it is subjected. This study proposes an Environmental and Natural Resource Accounting (ENRA) framework for the forest resource in Sri Lanka. The economic values of marketed and non-marketed commodities are estimated by various techniques. Changes in the monetary value of the timber stock are computed from estimated economic accounts, using the net price method. The results for 1995 put the TEV of the forest resource at Rs 13,400 million. The total depreciation of forest timber stock in 1995 was Rs 116 million. The true contribution of the forest resource to the National Income (NI) was 2.24\% of the Gross Domestic Product (GDP). However, the contribution of the forest resource as estimated by the traditional SNA was reported by the Central Bank of Sri Lanka as only $0.2 \%$ of the GDP. This misleading estimate mav have led to under-investment in the forestry sector in the past. This past under-investment needs to be compensated for in the future national investment in forestry.
\end{abstract}

\section{Introduction}

Development planning relies on National Income (NI) accounts to guide economic policies and to measure development. The $\mathrm{NI}$ is the monetary valuc of the commodities produced in a country during a year. Conservation of natural resources is imperative if sustainable development is to be achieved. The traditional System of National Accounts (SNA) neglects the value of the natural resources and the environment. Its estimate of the NI therefore provides a misleading indication of the trie income of Sri Lanka. Development planning and investment that rely on a misleading economic indicator may not result in sustainable development.

There are several deficiencies in the traditional SNA:

- It treats man-made capital (buildings, machinery, etc) and natural capital (land, forests, biodiversity, etc) inconsistently. Man-made capital is depreciated in order to calculate 
the country's sustainable income - Net National Product (NNP) ${ }^{*}$, but the depreciation of natural capital does not appear in the accounts.

- It fails to measure sustainable development correctly, because it does not reflect the negative impacts of environmental degradation which are caused by economic activities.

- It includes expenses for the restoration of damaged environmental assets as a positive contribution to NI.

- It does not capture the Total Economic Value (TEV) of the natural and envirommental resources.

These deficiencies in the traditional SNA point to the need for an accounting framework in which the values of natural resources and of their degradation are taken into consideration, ie. for Environmental and Natural Resource Accounting (ENRA) framework. This study proposes the use of Peskin's framework for ENRA in Sri Lanka. It demonstrates the applicability of this framework, using data from the Sri Lanka forestry sector

\section{Literature review}

\section{The Forest Resource in Sri Lanka}

Before the twentieth century. about $80 \%$ of the land of Sri Lanka was covered by natural forests. During the last $40-50$ years much of this natural resource has been destroyed. According to an inventory made in 1992, the natural closed-canopy forest cover was then only about $23.8 \%$ of the land area.

The forest resource serves many diverse functions. Those listed in Table 1 are all economic finctions; as they contribute to human welfare either directly or indirectly. However not all of the services provided are associated with market values, and so they are not all included in the traditional SNA.

Table 1 : Economic functions of forests

\begin{tabular}{lll}
\hline $\begin{array}{l}\text { Source of materials and } \\
\text { services }\end{array}$ & Sink for waste & General and life support \\
\hline Timber & Absorption of waste & Genetic pool \\
Fuelwood & Recycling nutrients & Climate regulation \\
Non timber products & Watershed protection & Carbon fixing \\
Genetic resources & Protecting soil quality and & Habitat for people, flora and \\
& crosion resistance & fauna \\
Agricultural production & & Aesthetic and spiritual source \\
Recreation and tourism & & Scientific data \\
\hline
\end{tabular}

Source: World Wide Fund (1990).

The stock of envirommental and natural resources is depreciated physically as well as economically during the production and consumption process of the economy. In order to

"NNP equals GNP minus the "capital consumption allowance" (a measure of depreciation.) 
estimate the depreciation of forest values this study uses Peskin's framework. This accounting framework first attempts to preserve all of the information currently available in the traditional $\mathrm{NI}$ accounting framework. Then, in addition to traditional accounting agents industrial. government and household - some accounts from a new agent, "nature", are incorporated. A consolidated modified national income and product account is presented in Appendix 1 .

\section{Methodology - Estimation of Value Added by the Forest Resource}

The values added by the different economic functions of the forest (both marketed and nonmarketed) are as follows:

\section{Round timber and fuel wood}

The natural forests provide only a fraction of the total supply of round timber. Of a total sustainable round timber supply of 1.46 million $\mathrm{m}^{3}$, natural forests provide only $0.63 \%$ and forest plantations about $5.40 \%$ while the rest is from non-forest wood sources, mainly home gardens. rubber and coconut plantations. This picture is similar for the fuelwood supply; the natural forests and forest plantations provide only $10.5 \%$ of the total (FSMP, 1995).

The value added by roundwood and fuelwood was calculated by the same methodology and assumptions as those used by the Department of Census and Statistics. It was estimated by a market-based approach, and projections of demand and supply, which put the value added by these products at about Rs 521.3 million for roundwood and 1120.1 for fuelwood. These contributions are only from natural forests and forest plantations, and exclude production from non-forest sources.

\section{Non-timber forest products}

Non-timber forest products (NTFPs) have an important role in the nural economy, and provide bencfits of considerable importance at national level. The Sri Lankan Ayurvedic medication system is highly dependent on the medicinal plants obtained from the forests. In addition NTFPs provide important raw materials for small industries, such as those based on rattans and bamboos, and also sources of nural employment. in collecting, processing, and trading. They also bring in a considerable amount of foreign exchange from exports.

To estimate the value added by NTFPs, this study uses the information gathered by a national survey on the traditional uses of the natural forest in Sri Lanka (IUCN, 1995). The national value of the NTFPs is computed by multiplying the average annual household income from NTFPs of the secretarial divisions. and the number of households in each division. The results show that the annual net value of NTFPs is Rs 3893 million. It is justifiable to take this income as valuc added by the NTFPs, on the assumption that no other material inputs have been used and that the income has been generated only from labour. 
Carbon sequestration

Among other air pollutants Carbon dioxide is important because of its contribution on global climate change. Plant photosynthesis absorbs carbon from the atmosphere. This study uses a methodology based on that of Ologa \& Brirol (1994) to value the carbon sequestration service of the forests. Quantification of the net absorption rate and the consequent value of the absorption service is based on three assumptions:

- Carbon uptake rate (CUR): This is defined as the amount of carbon removed from the atmosphere and stored per unit area of forest per year. In this study a mean CUR of $2.7 \mathrm{ac} / \mathrm{yr}(6.8 \mathrm{t} / \mathrm{ha} / \mathrm{yr})$ was used.

- Energy related carbon emission: The carbon emission values of different fuel types, including fuelwood, are considered in the calculation of the total energy consumption balance. This study used the values estimated by Kato (1992) for the carbon emission factors (as tons of carbon per ton of oil-equivalent) as follows: coal 1.065; oil 0.859; gas 0.613; wood 1.19 .

-Valuing the carbon seqestration service: The cost of reforestation that is required to sequestrate a ton of carbon was considered. It was estimated by Ologa and Brirol (1994) at US\$13 (Rs 665)per ton of carbon". The monetary value of the carbon seqestration service of forests was estimated by multiplying the carbon emission in 1995 (6436 thousand tons) by Rs 665. The estimated value of the carbon sequestration service of the forests in 1995 was therefore Rs 4280 million.

\section{Hydrological benefits}

The hydrological benefits of the Sri Lankan forests can be catcgorized as agricultural and domestic water benefits, flood mitigation, watershed protection, etc. In this study an attempt is made to value the agricultural and domestic water benefits. The rationale is that it is the water retained by the forests during the wet scason that is slowly released into the streams to be available for agricultural needs during the dry season.

Agro-hydrological value: The "effect-on-production" method was used to derive an estimate for the agro-hydrological benefits. A part of the economic value of the crop which is planted in the dry season under irrigation was taken as a proxy for this agro-hydrological value. The value added by the total production of paddy, vegetables and highland crops (other field crops) to the GDP in 1995 was, respectively, 17,$160 ; 23,750$; and 17,310 million rupees. Irrigated production of paddy, vegetables, and highland crops was 74,47 and $41 \%$ of the total crop (Department of Agriculture, 1995). Based on the information on production losses associated with water stress, an assumption was made here of a moderate $10 \%$ reduction in production if there was no irrigation. The estimated value of the agro-hydrological benefit in 1995 then came to Rs 3095 million. However, this value should be included in the NI accounts only after deducting the same amount from the value of agricultural production, to avoid double counting.

* The average exchange rate in 1996 was about Rs 51 per dollar. The (metric)tonne and the (American "long") ton are about the same. 
Domestic water value: The storage and supply characteristics of forests facilitate year round abstraction of water to supplement the domestic and industrial water supply of the $25 \%$ of the population who obtain water from organized supplies. Each year about 274.7 million $\mathrm{m}^{3}$ of water are abstracted directly from the natural streams by the National Water Supply and Drainage Board, which handles about $65 \%$ of the organized water supply of Sri Lanka. The average total cost of production of purified water is about eleven rupees per $\mathrm{m}^{3}$, of which $15 \%$ is spent for purification (removal of suspended matter and disinfection). Based on Malaysian experience an assumption was made here. that a 25\% additional treatment cost is due to the clearance of forests (Kanta Kumari, 1995). This incremental treatment cost was used as a surrogate for domestic water benefits derived from the forest cover of Sri Lanka On this basis, the estimated domestic water value of the forests in 1995 was about Rs 115 million.

\section{Biodiversity}

Sri Lanka is one of the smallest but most biologically diverse countries in Asia (NARESA. 1991). The conservation of forests with high biodiversity gives the forests an added value. which should be incorporated into the SNA as a positive environmental value. A modified version of the Pearce \& Moran (1994) model, which estimates the pharmaceutical prospccting value (an option value) of biodiversity, was applied to the Sri Lankan forest resource. Note. however, that this model estimates only one component of biodiversity. In 1995. the estimated pharmaceutical prospecting value of biodiversity in the Sri Lankan natural forests was Rs 101 million. A summary of the Sri Lankan forest values in 1995 is illustrated in Fig. 1.

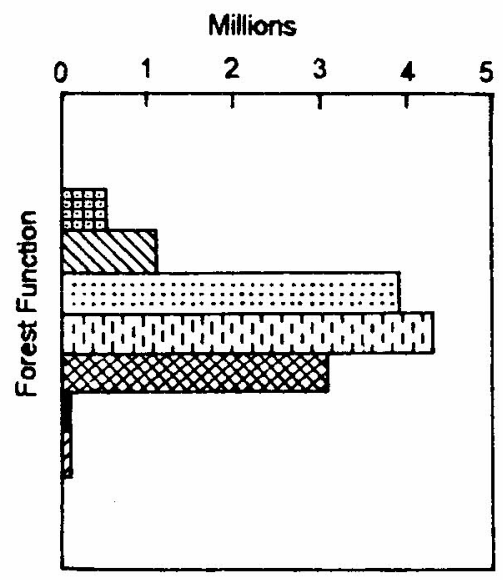

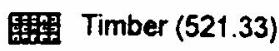

AVI Fuel Wood (1120.1)

N::: NTFP (3893.28)

[1. Carbon Sequestration (4286.4)

Agro-Hydro Benifits (3095.47)

Domestic water Value (114.88)

EA] Biodiversity (100.94)

Figure 1 - Total economic value of forests in 1995

* Kotagama \& Thushantha (1996) give the details of this model. 


\section{Methodology of valuing changes in the forest timber stock}

This study is based on the 1992 forest inventory results for natural forests, as Lowland Rain Forests (LRF), Moist Monsoon Forests (MMF), Dry Monsoon Forests (DMF) and on Forest Department (FD) information for Forest Plantations (FP). Changes in the stocks of LRF, MMF, DMF and FP were first computed by the development of physical accounts. The volume accounts for the accounting year 1995 were derived by applying stocking densities for natural forests and forest plantations to the corresponding area accounts. The stocking density figures used were $126 \mathrm{~m}^{3} / \mathrm{ha}$, for LRF, $39 \mathrm{~m}^{3} / \mathrm{ha}$ for MMF, and $21 \mathrm{~m}^{3} / \mathrm{ha}$ for DMF. Stocking densities for FP were worked out from average FD volume statistics of the FD.

The basic year-to-year accounting procedure for extractive products (timber) from the forests is as follows. For a given accounting year the physical amount in volume terms starts with an opening stock at time t. Two types of transactions are included:

- addition in the form of natural stand growth, and

- reduction in the form of harvest, waste, stand mortality or forest conversion (deforestation).

Addition by reforestation and plantation development is treated as a separate account.

Addition minus reduction results in net change in stock, which is added algebraically to the opening stock in order to estimate the closing stock for that year. The end-of-year figure then becomes the opening stock of the next accounting year. Depreciation or appreciation was then estimated using the net-price method, which depends primarily on the market values of derived products.

The change in resource stock in the physical (volume) accounts for an accounting period is expressed in monetary terms by the net price method.

Where:

$$
\text { depreciation }^{*}=(\text { change in stock })_{t} \times(\text { average net price })_{t}
$$

(change in stock $)_{t}=(\text { opening stock })_{t}-(\text { closing stock })_{t}$

(net price of timber in year $)_{t}=(\text { average output price per unit })_{t}$

- (direct unit production cost $)_{t}$

- (margin for profit and risk)t

\section{Depreciation estimates}

In 1995 the natural forests, excluding Sub montane rain forest, montane rain forest and open canopy forests, declined by about 19,300 ha while forest plantations increased by about 700 ha. In order to represent different forest types having different mixtures of tree species,

* The change in asset value over time. 
an average net price was used, based on different mixtures. The average net prices used for LRF, DMF and MMF were 481,1260 and $569 \mathrm{Rs} / \mathrm{m}^{3}$ respectively.

The net depreciation resulting from change in the physical stock of the forests was greatest for the DMF. at about Rs 378 million; for the LRF it was about 109 million; and for the MMF about.71 million. Plantation forests have appreciated by Rs 83, 56 and 7 million for teak. mahogany and eucalypts respectively. The positive change in plantations, therefore. has not been sufficient to compensate for natural-forest timber losses

The total depreciation of the forests in 1995 was about Rs 416.4 million. This figure would vary somewhat if other natural forests and plantations were taken into account. Fig. 2 illustrates the depreciation/appreciation values of the forest resource in 1995.

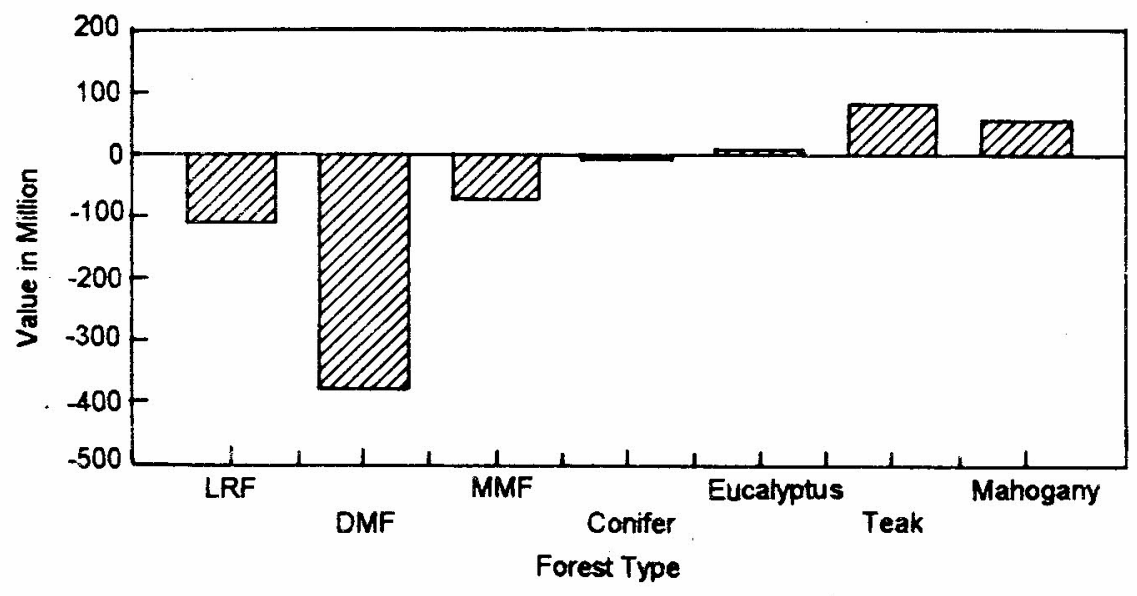

Figure 2 - Value of the changes in the timber stock in 1995

\section{Conclusions and policy implications}

The traditional SNA neglects the value addition by natural resources and the depreciation of natural capital, so that GDP is underestimated and NDP is overstated. For a developing country like Sri Lanka, this overstatement can have adverse effects on policy making. Policies that successfully maximize overstated income may produce short-run gains at the expense of long-run impoverishment. In contrast, policies that maximize sustainable income (modified NNP) will have a greater chance of generating an increasing income that will make future generations as well off, or better off, than present generation. 
An ENRA study can be used to inform decision makers and raise awareness about how the environment and natural resource stocks change over time and to quantify the way in which changes in the environment affect the economy. It will enable policy makers to determine policies that will achieve sustainable development and ensure that the wealth of the nation does not decrease over time.

Another aspect of ENRA is the use of the economic rent (price of natural resources) concept to influence policy in determining the level of royalties and charges that the natural resource users must pay. So far royalty rates have been determined arbitrarily, and a considerable portion of economic rent has not been captured by the government.

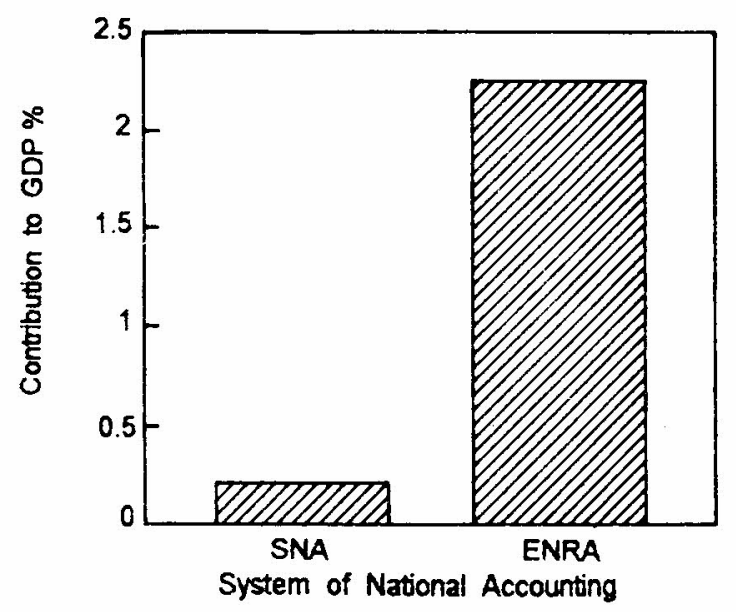

Figure 3 - Forestry sector contribution to the GDP in 1995

Of the comprehensive process of ENRA, this study demonstrated accounting only for a single, but important. resource, the forests. It has shown that in 1995 the TEV of natural forests and forest plantations was Rs 13,400 million. The forestry sector contribution to the NI was therefore about 2.24 per cent of the GDP, whereas the contribution of natural forests and forest plantations, as estimated by the traditional SNA, was reported by the Central Bank of Sri Lanka as only $0.2 \%$ of the GDP. This sort of information will have lead to underinvestment in the forestry sector in the past. This tendency needs to be rectified in the future national investment.

Natural resource depreciation was estimated only for timber stocks in the LRF, MMF, DMF, and FP. The study found that in 1995 there had been a physical depletion of the Sri Lankan forests of 18,600 ha, or in economic terms Rs 416.4 nillion. This depreciation of forests has not been accounted for in the traditional SNA. The NNP has been overestimated, and the loss of forest productivity has been overlooked in national investment.

A study that can produce a comprehensive ENRA (including all natural resources) is needed by the Department of National Planning. for incorporation into the national development 46 
indicators. This study demonstrated the possibility of applying ENRA in Sri Lanka. The methodology could be further improved and applied by national institutions with appropriate institutional arrangements.

\section{References}

Central Bank of Sri Lanka (1996). Annual Report, 1995. Colombo, Central Bank of Sri Lanka.

Department of Census and Statistics (1995). Demographic Survey, 1994. Colombo, Department of Census and Statistics.

Deparument of Census and Statistics (1995). National Accounts of Sri Lanka, 1994. Colombo, Department of Census and Statistics.

Forestry Planning Unit (1995). Sri Lanka Forestry Sector Master Plan. Battaramulla, Ministry of Agriculture, Land and Forestry.

Grambsch, A., Michaels. R.G. and Peskin, H. M. (1993). Taking stock of nature: environment accounting for (hesapeake Bay. In: Lutz, E. (Ed.) Toward improved accounting for the nature. Washington, World Bank.

Gunatillake, I.A.U.N. and Gunatillake, C.V.S. (1991). Natural forests of Sri Lanka. Faculty of Science, University of Peradeniya (mimeo).

IUCN (1995). Traditional use of forest in Sri Lanka: a national survey. Report prepared for the Forest Department of Sri Lanka.

IRG (1992). The Philippine Natural Resources Accounting Project (NRAP-Phase 1): main report. Repon prepared for the Department of Environment and Natural Resources, Philippines.

Kanta Kumari. (1995). An environmental and economic assessment of forest management options: a case study in Malaysia. Ph.D.Thesis, University of East Anglia.

Lutz, E. and Molan Munasinghe (1991). Accounting for the cnvironmc.at, Finance and Development.

NARESA. 1991, Natural Resources of Sri Lanka, Conditions and Trends. A report prepared for the natural resources, enery and science authority of Sri Lanka.

Okogu, B.E. and Birol, F. (1994). Valuing carbon sequestration services of developing countries' forests. Development Policy Review. 12, 355-368.

Simpson, R.D. and Sedjo, R.A. (1993). Valuing biodiversity: an application of "green accounting". Washington, Resources for the Future. 
Annual Forestry Symposium, 1996

Appendix 1: Consolidated Modified National Income and Product Accounts

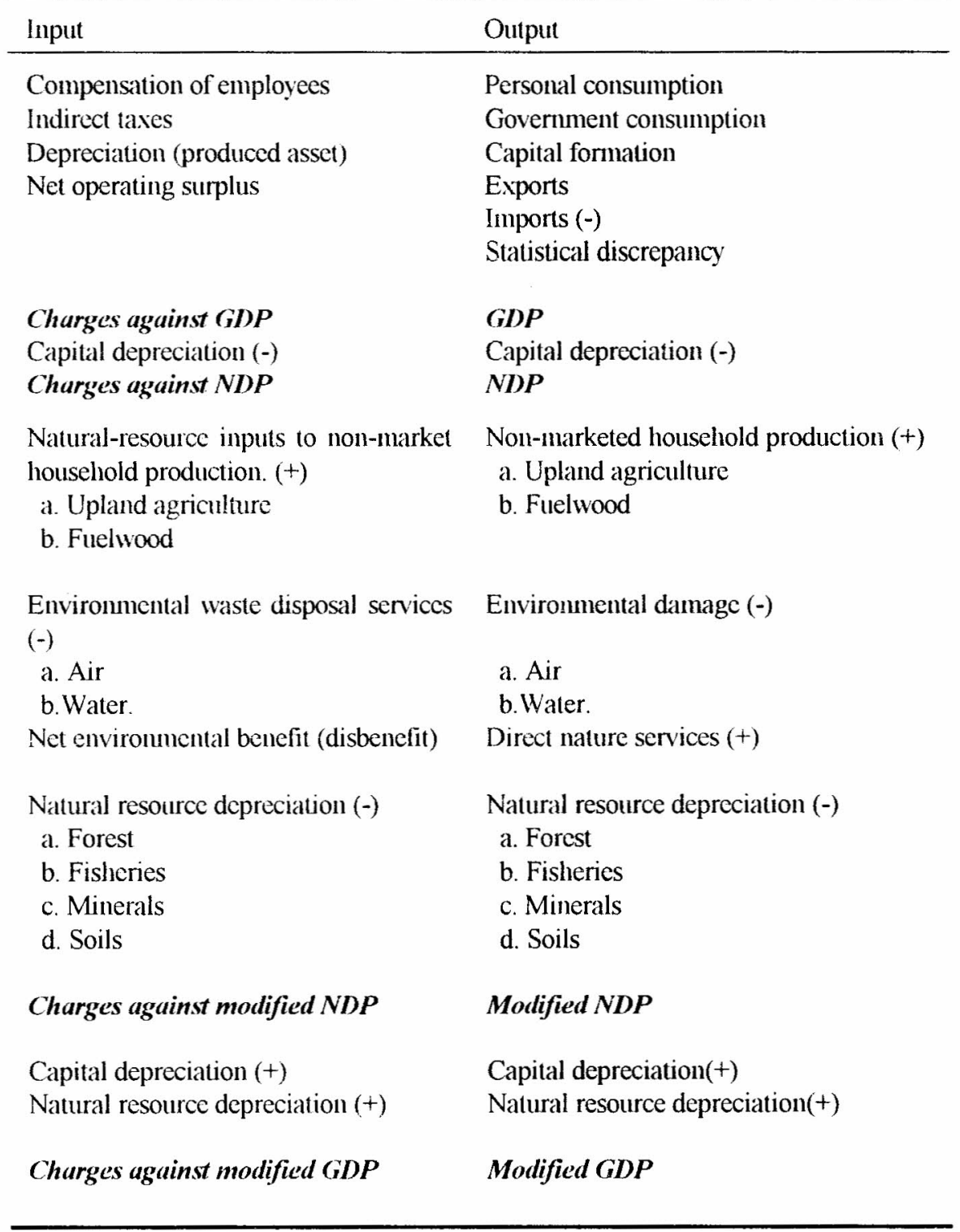

Source: Peskin, H.M. (1989). Accounting for natural resource depletion and degradation in developing countrics. Environment Department Working Paper No. 13. World Bank.

\section{8}

